\title{
Strategi Peningkatan Kinerja Distributor Pada Tiens International Group Di Bandar Lampung
}

\author{
M Yusuf S Barusman, Santaliya Sanjaya, Appin Purisky Redaputri \\ Fakultas Ekonomi dan Bisnis, Universitas Bandar Lampung, Indonesia \\ Email : \\ yusuf.barusman@ubl.ac.id \\ santaliya.13011009@student.ubl.ac.id \\ appin@ubl.ac.id
}

\begin{abstract}
ABSTRAK
Dalam suatu sistem operasi perusahaan, potensi Sumber Daya Manusia merupakan salah satu modal dan memegang suatu peran yang paling penting dalam mencapai tujuan perusahaan. Tiens International Group merupakan sebuah Group yang bergerak dibidang usaha penjualan yang menggunakan sistem berjenjang, sehingga Sumber Daya Manusia merupakan kunci utama penggerak dalam bisnis ini. Permasalahan yang terjadi adalah rendahnya kinerja para distributor Tiens International Group dilihat dari tidak tercapainya target yang diberikan para leader. Penelitian ini bertujuan untuk mengetahui penyebab tidak tercapainya target distributor dan strategi yang tepat diterapkan kepada distributor Tiens International Group di Bandar Lampung. Penelitian ini menggunakan desain penelitian kualitatif. Teknik pengambilan sampel yang digunakan dalam penelitian ini adalah teknik purposive sampling, sebanyak tiga orang sebagai narasumber. Metode pengumpulan data dilakukan secara langsung dengan menggunakan alat perekam suara dan data pertanyaan yang diberikan kepada distributor Tiens Bandar Lampung, sedangkan analisis yang digunakan untuk mengetahui terbukti atau tidak suatu penelitian menggunakan telaah proposisi yang berisi pembuktian atau tidak dari hasil pengamatan, hasil wawancara, dan teori para ahli. Hasil penelitian ini diketahui bahwa tidak tercapainya target disebabkan karena kurangnya edukasi terhadap prospek negative dan strategi yang tepat diterapkan pada Tiens International Group ini dibagi menjadi 3 pengertian strategi sesuai dengan klasifkasi masing - masing distributor.
\end{abstract}

\section{Kata Kunci: Strategi Peningkatan Kinerja; Studi Kasus;Kualitatif} \section{PENDAHULUAN}

Setiap perusahaan memiliki satu kunci penting dalam roda perputaran usahanya, yaitu Sumber Daya Manusia. Karena SDM memiliki peran penting dalam mencapai tujuan perusahaan. Oleh karena itu perusahaan perlu mengelola Sumber Daya Manusia sebaik mungkin. Sumber daya manusia merupakan tokoh sentral dalam organisasi maupun perusahaan. Agar aktivitas manajemen berjalan dengan baik, perusahaan harus memiliki pegawai yang berpengetahuan dan berketrampilan tinggi serta usaha untuk mengelola perusahaan seoptimal mungkin sehingga kinerja pegawai meningkat. Kinerja pegawai merupakan hasil atau prestasi kerja pegawai yang dinilai dari segi kualitas maupun kuantitas berdasarkan standar kerja yang ditentukan oleh pihak organisasi.

TIENS Internasional Group di Bandar Lampung merupakan sebuah Group yang bergerak dibidang usaha penjualan barang dimana produknya berupa supplement herbal dan alat kesehatan yang memiliki banyak manfaat dan menggunakan sistem berjenjang atau yang biasa disebut Multi Level Marketing ( MLM ) dalam proses pemasaran dan penjualanya. MLM termasuk dalam network marketing. Network Marketing atau biasa disebut bisnis jaringan atau pemasaran jaringan, merupakan suatu pemasaran dengan sistem keanggotaan untuk memasarkan produknya. Namun permasalahannya saat ini adalah kinerja distirbutor pada konteks ini adalah distirbutor TIENS Internasional Group di Bandar Lampung di indikasikan masih rendah, tidak tercapainya target distributor baru yang ditentukan oleh para leader TIENS Internasional Group di Bandar Lampung Periode 2015 - 2016. 
Tabel 1.1 Persentase Pencapain Target

Distributor Baru TIENS Internasional Group

Bandar Lampung

Periode November 2015 - Oktober 2016

\begin{tabular}{|c|c|c|c|}
\hline Bulan & $\begin{array}{c}\text { Target } \\
\text { (Orang) }\end{array}$ & $\begin{array}{c}\text { Realisasi } \\
\text { (Orang) }\end{array}$ & Persentase \\
\hline November & 10 & 8 & $80 \%$ \\
\hline Desember & 15 & 13 & $86,7 \%$ \\
\hline Januari & 25 & 22 & $88 \%$ \\
\hline Februari & 40 & 30 & $75 \%$ \\
\hline Maret & 60 & 53 & $88,3 \%$ \\
\hline April & 80 & 76 & $95 \%$ \\
\hline Mei & 95 & 95 & $100 \%$ \\
\hline Juni & 105 & 100 & $95,2 \%$ \\
\hline Juli & 120 & 117 & $97,5 \%$ \\
\hline Agustus & 135 & 128 & $94,8 \%$ \\
\hline September & 150 & 142 & $94,7 \%$ \\
\hline Oktober & 165 & 164 & $99,4 \%$ \\
\hline
\end{tabular}

Berdasarkan data terlihat pencapai target distributor baru tidak sesuai harapan dari target yang diberikan oleh para Leader TIENS Internasional Group di Bandar Lampung. Hanya pada bulan Mei perekrutan distributor baru tercapai.

Untuk itu perlu diketahui penyebab tidak tercapainya target yang telah ditetapkan oleh para leader dan untuk mengetahui strategi apa yang tepat untuk meningkatkan kinerja distributor pada TIENS International Group di Bandar Lampung.

\section{METODOLOGI PENELITIAN}

Desain penelitian ini menggunakan design penelitian kualitatif. Penelitian kualitatif adalah penelitian riset yang bersifat deskriptif dan cenderung menggunakan analisis serta lebih menonjolkan proses dan makna. Penelitian kualitatif merupakan sebuah cara yang lebih menekankan pada aspek pemahaman secara mendalam terhadap suatu permasalahan.
Menurut Sugiyono $(2009: 15)^{1}$ penelitian kualitatif adalah suatu metode penelitian yang berlandaskan pada filsafat postpositivisme, digunakan untuk meneliti pada kondisi objek yang alamiah dimana peneliti adalah sebagai instrumen kunci, pengambilan sampel sumber data dilakukan secara purposive, teknik pengumpulan dengan triangulasi, analisis data bersifat induktif/kualitatif, dan hasil penelitian kualitatif lebih menekankan makna daripada generalisasi.

Dalam penelitian ini data diperoleh dengan menyebarkan angket yang berisikan pertanyaan-pertanyaan yang sesuai dengan teori yang digunakan dalam penelitian dan pokok permasalahan dalam penelitian ini. Pokok permasalahan ini dapat berkembang sehingga ditemukan informasi lain yang berhubungan dengan pokok permasalahan tersebut selama wawancara berlangsung.

Dalam melakukan penelitian, dibutuhkan data- data yang bersumber dari objek yang akan diteliti agar permasalahan dapat dipecahkan. Pengambilan data dalam penelitian ini dilakukan dengan cara observasi, wawancara semi terstruktur, dokumentasi dan catatan pengamatan. Menurut Arikunto (2010) ${ }^{2}$ observasi adalah pengamatan langsung dari lingkungan fisik atau pengamatan langsung suatu kegiatan yang sedang berlangsung yang mencakup semua kegiatan perhatian ke objek dengan menggunakan alat penilaian sensorik. Atau suatu pekerjaan yang dilakukan dengan sengaja dan sadar untuk mengumpulkan data dan melaksanakan prosedur yang sistematis dan tepat. Pada teknik pengambilan data observasi, menggunakan observasi metode terus terang atau tersamar dimana dalam melakukan pengumpulan data menyatakan terus terang kepada sumber data, bahwa sedang melakukan penelitian.

$$
\text { Menurut Arikunto (2006: 158) }{ }^{3}
$$

dokumentasi adalah mencari dan mengumpulkan data mengenai hal-hal seperti catatan, transkrip, buku, surat kabar, majalah, prasasti, notulen rapat, legger, agenda, dan sebagainya. Penelitian ini mengambil data melalui skripsi-skripsi terdahulu, buku-buku pengarang tertentu, dan website. Menurut Sugiyono (2009:317) ${ }^{1}$ Wawancara adalah pertemuan dua orang untuk bertukar informasi dan ide melalui tanya jawab sehingga dapat dikonstruksikan makna dalam suatu topik tertentu dan dengan wawancara, dalam hal ini kita akan mengetahui hal-hal yang lebih mendalam tentang partisipan dalam mengintreprestasikan situasi dan fenomena yang 
terjadi yang tidak mungkin bisa ditemukan melalui observasi. Dalam hal ini, peneliti melakukan tanya jawab atau wawancara secara langsung kepada para leader Tiens Internasional Group. Tujuan dari wawancara adalah untuk mendapatkan informasi di mana pewawancara melontarkan pertanyaan-pertanyaan untuk dijawab oleh orang yang diwawancarai.

Miles dan Huberman dalam Emzir $(2010)^{4}$ menyatakan bahwa terdapat tiga macam kegiatan analisis data kualitatif, yaitu: pengumpulan data, reduksi data, penyajian data dan penarikan kesimpulan.

Menurut Sutrisno Hadi (2005:150) ${ }^{5}$ yang dimaksud populasi adalah kumpulan individu individu dalam suatu daerah. Teknik sampling yang digunakan purposive sampling. Purposive sampling adalah teknik pengambilan sampel sumber data dengan pertimbangan tertentu. Pertimbangan tersebut misalnya orang tersebut dianggap paling tahu tentang apa yang kita harapkan. Dalam penelitian ini terdapat 3 narasumber, yang pertama Bapak Rian, yang kedua NN dan yang terakhir Bapak Made Irawan. Jenis penelitian yang digunakan dalam penelitian ini adalah penelitian kepustakaan, penelitian lapangan, dan penelitian studi kasus.

Validitas internal (Yin, 2003) ${ }^{6}$ terdiri dari pencocokan pola, membangun penjelasan dan menggunakan model logis. Selain ketiga teknik validitas internal tersebut, penelitian ini juga menggunakan trianggulasi untuk meningkatkan validitas internal. Trianggulasi yang digunakan bisa meliputi trianggulasi data, trianggulasi informan, trianggulasi investigator, trianggulasi teori dan trianggulasi metodologi,namun dalam penelitian ini trianggulasi yang digunakan adalah trianggulasi data dan trianggulasi informan saja. Dan teknik uji validitas eksternal lainnya yang dapat dilakukan adalah dengan melakukan thick description (Denzin, 1994) ${ }^{7}$. Thick Description adalah prinsip penyamarataan menggugah pembaca penelitian untuk menganalisis sampai sejauh mana kemampuan suatu penelitian untuk dapat diterapkan ke situasi yang dialami oleh pembaca penelitian.

Tujuan dari uji ini adalah untuk memastikan bahwa peneliti berikutnya mengikuti prosedur yang sama dengan peneliti terdahulu dan dengan melakukan lagi studi kasus yang sama, peneliti berikutnya harus sampai pada hasil temuan dan kesimpulan yang sama. Salah satu prasyarat agar investigator yang lainnya dapat mengulangi studi kasus yang sama adalah dengan mendokumentasikan prosedur-prosedur yang dilakukan pada kasus terdahulu.

Cara umum untuk mengatasi masalah reliabilitas ini adalah dengan membuat langkahlangkah operasional sebanyak mungkin dan melakukan penelitian seolah-olah ada orang lain yang selalu mengamati. Uji reliabilitas menunjukkan bahwa langkah-langkah operasional studi seperti misalnya prosedur pengumpulan data dan lain-lain dapat diulangi dengan memberikan hasil yang sama. Penelitian ini mengikuti Yin $(2003)^{6}$, yang mengemukakan bahwa ada dua teknik utama untuk meningkatkan reabilitas yaitu dengan menggunakan prosedur studi kasus dan mengembangkan basis data studi kasus. Sedangkan tahapan penelitian dalam penelitian ini ada empat yaitu : tahap konseptual, tahap observasi, tahap pengumpulan data dan tahap analisis data.

\section{HASIL DAN PEMBAHASAN}

\section{Gambaran umum Tiens International Group}

Pendiri Tiens Internasional Group adalah Bapak Li Jin Yuan yang kini menjabat sebagai Direktur Utama, Presiden Tiens Internasional Group dan ketua Dewan Direksi, CEO TIENS Bio Tech Group (USA) Inc. Didirikan pada tahun 1995 di kawasan pengembangan $\mathrm{Wu}$ Jing, Taman Industri Teknologi Baru di Tianjin, Tiens Group Co., Ltd ( selanjutnya di sebut "Tiens International Group" ) memasuki pasar Internasional pada tahun 1997. Hingga kini Tiens International Group telah menjadi grup multinasional yang spesialis di bidang bioteknologi, pendidikan, ritel, pariwisata, keuangan, perdagangan Internasional, E-bisnis dan bidang-bidang lainnya, dengan menyatukan modal industri, modal komersial dan modal keuangan. Usaha meliputi di lebih dari 190 negara dan daerah, Tiens International Group memiliki anak perusahaan atau cabang di 110 negara serta daerah.

Pada Tiens Internasional Group terdapat beberapa peringkat, dimana peringkat ini dibagi menjadi 3 yaitu tahap pendaftaran, tahap penduplikasian diri, dan tahap kehormatan. Tahap pertama adalah tahap pendaftaran terdapat 3 peringkat yaitu $* 1, * 2, * 3$ dengan cara : mengisi formulir pendaftaran sesuai dengan KTP, memberikan biaya pendaftaran sebesar Rp 99.000 , dan kemudian melakukan pembelian produk (minimal 1 produk). Dengan demikian calon ditstributor telah resmi bergabung dan mendapatkan peringkat $* 1$. 
Tahap kedua adalah tahap penduplikasian diri mulai dari $* 4-* 8$. Tahap ini disebut dengan penduplikasian diri karena, masing - masing distributor yang telah bergabung akan mengajak orang - orang untuk bergabung dengan cara yang sama seperti yang telah mereka lakukan. Sehingga untuk terus mencapai peringkat yang lebih tinggi, maka distributor harus terus memelihara jaringan mereka seperti yang telah dilakukan upline mereka.

Tahap ketiga adalah peringkat kehormatan, pada peringkat ini distributor tidak perlu lagi mencari downline. Karena bonus mereka sudah diperoleh seumur hidup. Dipertingkat kehormatan ini ada 6 tingkatan yaitu : Bronze Lion, Silver Lion, Gold Lion, 5 Diamond Gold Lion, Director, dan Executive Director.

\section{Gambaran Umum Kinerja Distributor}

Menurut Ambar Sulistyani $(2002: 87)^{8}$ kinerja seseorang dapat dilihat dari :

1. Prestasi kerja, adalah hasil kerja yang dicapai dalam melaksanakan tugas yang diberikan kepadanya. yang dipengaruhi oleh kecakapan. pengalaman dan kesungguhan yang bersangkutan.

2. Kesetiaan, adalah kesanggupan untuk menaati, melaksanakan dan mengamalkan sesuatu yang ditaati dengan penuh kesadaran dan tanggung jawab yang dibuktikan melalui sikap dalam melaksanakan tugas sehari-hari.

3. Tanggung jawab, adalah kesanggupan pegawai dalam menyelesaikan pekerjaan yang diserahkan kepadanya dengan sebaik-baiknya dan tepat waktu, serta berani memikul resiko atas keputusan yang diambil.

4. Ketaatan, adalah kesanggupan seorang pegawai untuk mentaati segala peraturan perundangan dan kedinasan yang berlaku.

5. Kejujuran, adalah ketulusan hati seorang pegawai dalam melaksansakan tugas dan kemampuan untuk tidak menyalahgunakan wewenang.

6. Kerjasama, adalah kemampuan seorang pegawai untuk bekerjasama dengan orang lain dalam menyelesaikan tugas yang diberikan sehingga mencapai daya guna dan hasil guna secara optimal.

7. Prakarsa, adalah kemampuan seorang pegawai untuk mengambil keputusan atau melaksanakan tindakan yang diperlukan dalam pelaksanaan tugas.
Tabel 1.2 Hasil Wawancara Kepada Distributor Tiens International Group Di Bandar

Lampung

\begin{tabular}{|c|c|c|c|}
\hline Indikator & $\begin{array}{c}\text { Narasum } \\
\text { ber 1 }\end{array}$ & $\begin{array}{c}\text { Narasum } \\
\text { ber 2 }\end{array}$ & $\begin{array}{c}\text { Narasum } \\
\text { ber 3 }\end{array}$ \\
\hline $\begin{array}{c}\text { Prestasi } \\
\text { Kerja }\end{array}$ & $\begin{array}{c}\text { Belum } \\
\text { Tercapai }\end{array}$ & $\begin{array}{c}\text { Belum } \\
\text { Tercapai }\end{array}$ & Tercapai \\
\hline Kesetiaan & Setia & Setia & Setia \\
\hline $\begin{array}{c}\text { Tanggung } \\
\text { Jawab }\end{array}$ & Maksimal & Maksimal & Maksimal \\
\hline Ketaatan & Baik & Baik & Baik \\
\hline Kejujuran & Baik & Baik & Baik \\
\hline Kerjasama & Baik & Baik & Baik \\
\hline Prakarsa & Baik & Baik & Baik \\
\hline
\end{tabular}

Dapat dilihat dari tabel perbandingan diatas bahwa berdasarkan prestasi kerja narasumber 1 dan 2 masih belum mencapai target dan narasumber 3 telah mencapai target. Yang akan di jelaskan faktor penyebabnya di tabel berikutnya.

Tabel 1.3 Faktor Perbandingan

Tercapainya Target Berdasarkan Prestasi Kerja

\begin{tabular}{|c|c|}
\hline \multicolumn{2}{|c|}{ Prestasi Kerja } \\
\hline Belum Tercapai & Tercapai \\
\hline $\begin{array}{l}\text { Masih kurangnya } \\
\text { pengalaman, dilihat } \\
\text { dari segi lamanya } \\
\text { bergabung } \\
\text { diperusahaan. }\end{array}$ & $\begin{array}{l}\text { Memiliki cukup } \\
\text { pengalaman berbisnis } \\
\text { diperushaan ini. }\end{array}$ \\
\hline $\begin{array}{l}\text { Karena masih kurang } \\
\text { kesadaran diri untuk } \\
\text { menjadi pedoman } \\
\text { downline nya. }\end{array}$ & $\begin{array}{lr}\text { Telah memiliki } \\
\text { kesadaran diri, bahwa } \\
\text { ia menjadi contoh } \\
\text { bagi } \\
\begin{array}{ll}\text { downlinenya. } & \end{array}\end{array}$ \\
\hline $\begin{array}{lr}\text { Sangat } & \text { terpengaruh } \\
\text { dengan } & \text { prospek } \\
\text { negative } & \\
\end{array}$ & $\begin{array}{l}\text { Sudah tidak } \\
\text { terpengaruh dengan } \\
\text { prospek negative }\end{array}$ \\
\hline
\end{tabular}

\section{HASIL OBSERVASI LAPANGAN}

Berdasarkan dari wawancara yang telah dilakukan, terdapat temuan lapangan yang telah dibagi berdasarkan indikator kinerja pegawai menurut Ambar Sulistyani $(2002: 87)^{8}$ sebagai berikut :

- Ketiga narasumber memiliki prestasi kerja yang beragam, 2 diantaranya masih belum mencapai target yang ditentukan.

- Mengenai kesetiaan, ketiga narasumber memiliki jawaban yang menyatakan kesediaan waktunya untuk mengutamakan kepentingan organisasi. 
- Dari tanggung jawab, ketiganya telah memiliki tanggung jawab dalam segi keterampilan mereka mengusahakan semaksimal mungkin.

- Ketaatan, ketiganya telah mengikuti aturan dalam pengadaan home meeting dan dengan disiplin tetap mengikuti aturan tersebut.

- Kejujuran, ketiganya telah melakukan presentasi sesuai dengan kenyataannya dan tidak merebut kontak calon distributor milik rekan satu jaringannya.

- Kerjasama, ketiganya telah melakukan team work yang sangat baik untuk membantu downline mereka.

- Prakarsa, didalam home meeting mereka bukan sekedar aktif membagi ide, tetapi mereka juga saling membagi pengalaman dan saling menyemangati.

\section{Gambaran Umum Tentang Strategi}

Menurut Henry Mintzberg (1998) ${ }^{9}$, seorang ahli bisnis dan manajemen, bahwa pengertian strategi terbagi atas 5 definisi yaitu :

- Pengertian strategi sebagai rencana adalah sebuah program atau langkah terencana (a directed course of action) untuk mencapai serangkaian tujuan atau cita cita yang telah ditentukan; sama halnya dengan konsep strategi perencanaan.

- Pengertian strategi sebagai pola (pattern) adalah sebuah pola perilaku masa lalu yang konsisten, dengan menggunakan strategi yang merupakan kesadaran daripada menggunakan yang terencana ataupun diniatkan. Hal yang merupakan pola berbeda dengan berniat atau bermaksud maka strategi sebagai pola lebih mengacu pada sesuatu yang muncul begitu saja (emergent).

- Definisi strategi sebagai posisi adalah menentukan merek, produk ataupun perusahan dalam pasar, berdasarkan kerangka konseptual para konsumen ataupun para penentu kebijakan; sebuah strategi utamanya ditentukan oleh faktor - faktor ekternal.

- Pengertian strategi sebagai taktik, merupakan sebuah manuver spesifik untuk mengelabui atau mengecoh lawan (competitor).

- Pengertian strategi sebagai perspektif adalah mengeksekusi strategi berdasarkan teori yang ada ataupun menggunakan insting alami dari isi kepala atau cara berpikir ataupun ideologis.

Di perusahaan sendiri telah diberikan 7 Langkah dalam menjalankan bisnis ini yaitu : Impian dan sikap, Pakai Produk, Buat Daftar Nama, Buat Janji Bertemu, Presentasi, Tindak Lanjut dan Gunakan Alat Bantu (cd, buku positif, d1l). Tetapi langkah ini masih kurang tepat untuk diterapkan pada masing - masing klasifikasi distributor, karena setiap klasifikasi memiliki karakteristik yang berbeda dan harus ditangani dengan strategi yang tepat. Maka saya membagi strategi yang telah ditetapkan perusahaan menjadi 3 strategi yang dirasa tepat untuk menghadapi masing - masing klasifikasi distributor.

Tabel 1.4 Klasifikasi Distributor Dan Strategi Yang Digunakan

\begin{tabular}{|c|c|c|}
\hline No. & $\begin{array}{c}\text { Klasifikasi } \\
\text { Distributor }\end{array}$ & $\begin{array}{c}\text { Strategi Yang } \\
\text { Digunakan }\end{array}$ \\
\hline 1. & $\begin{array}{c}\text { Calon Distributor } \\
\text { (Belum Bergabung) }\end{array}$ & $\begin{array}{c}\text { Strategi } \\
\text { Sebagai Pola }\end{array}$ \\
\hline 2. & $\begin{array}{c}\text { Distributor } \\
\text { (Tahap } \\
\text { Pengembangan } \\
\text { karir) }\end{array}$ & $\begin{array}{c}\text { Strategi } \\
\text { Sebagai } \\
\text { Prespektif }\end{array}$ \\
\hline 3. & $\begin{array}{c}\text { Konsumen } \\
\text { (Hanya } \\
\text { Mengkonsumsi } \\
\text { Produk) }\end{array}$ & $\begin{array}{c}\text { Strategi } \\
\text { Sebagai Posisi }\end{array}$ \\
\hline
\end{tabular}

Berdasarkan tabel diatas dapat diketahui tingkatan atau klasifikasi distributor dengan strategi yang berbeda - beda. Yang pertama cara menghadapi calon distributor, pertama distributor yang akan melakukan presentasi kepada calon distributor akan diberikan tahap - tahap yaitu sebagai berikut :

1. Membuat daftar nama, ditahap ini distributor yang telah bergabung dengan perusahaan akan diarahkan untuk membuat daftar nama dan kontak masing - masing, baik sanak saudara maupun teman ataupun hanya kenalan.

2. Hubungi, ditahap ini distributor menghubungi setiap nama - nama dari daftar nama yang tadi telah dibuat, kemudian buat janji untuk bertemu.

3. Presentasi, biasanya disebut juga one on one ditahap ini distributor akan melakukan presentasi kepada calon distributor namun hanya secara garis besar saja.

4. Ajak bergabung, ditahap ini calon distributor akan diberikan selembar formlir pendaftaran dan akan diajak ke stokis.

5. Jika bergabung, maka selanjutnya diajak ke home meeting ataupun pertemuan pertemuan untuk terus mengasah keterampilannya dalam melakukan presentasi. Selain itu dapat terus menambah semangat para distributor. 
Dan strategi ini disebut strategi sebagai pola, karena cara setiap distributor untuk mengajak calon distributor bergabung bersifat konstan. Tahapan - tahapan ini telah diterapkan oleh leader-leader.

Strategi yang tepat untuk distributor yang sedang dalam tahap pengembangan karir, maka strategi yang tepat digunakan adalah strategi sebagai perspektif. Karena strategi ini lebih menggunakan insting alami dari isi kepala atau cara berpikir ataupun ideologis yang dirasa tepat untuk pengambangan karir. Dimana tahapan untuk mencapai jenjang karir yang lebih tinggi akan menghadapi tantangan yang lebih besar lagi dan akan memerlukan pengalaman dan insting alami dari distributor itu sendiri. Cara cara untuk meningkatkan pengalaman dan insting alami adalah seperti memperbanyak membaca buku - buku positif agar kita selalu berpikiran positif dalam menghadapi setiap tantangan baru, lebih sering mendengarkan rekaman leader seluruh dunia atau biasa disebut Net-P untuk menambah motivasi - motivasi agar kita terus terpacu untuk lebih giat bekerja dan lebih sering melakukan prospek untuk menambah pengalaman dan mengasah keterampilan dalam berbicara.

Sedangkan untuk menghadapi konsumen, maka strategi sebagai posisi ini adalah salah satu strategi yang cocok untuk digunakan. Karena untuk menentukan produk apa yang akan cocok dikonsumsi oleh konsumen (calon distributor yang mau bergabung tetapi hanya ingin menjadi konsumen untuk mendapatkan diskon member) maka kita harus melakukan beberapa tahapan sebelum memberikan saran produk. Tahap pertama, kita harus mengetahui konsumen memiliki riwayat penyakit tertentu atau keluhan yang dihadapi sehari - hari. Ditahap ini bisa ditanyakan langsung dengan konsumen atau bisa menggunakan alat kesehatan yang dimiliki distributor, jika distributor tidak memiliki alat kesehatan tersebut maka distributor dapat membawa konsumen untuk menghadiri pertemuan seperti home meeting ataupun opportunity preview (OP) karena biasanya di pertemuan tersebut para upline dapat mendemonstrasikan alat kesehatan.

Tahap kedua adalah memberikan saran produk kesehatan, seperti pembersih (detox), produk penyeimbang, produk penguat dan alat kesehatan. Tahap ketiga, kita melakukan penjelasan cara konsumsi dan cara kerja produk tersebut serta manfaat dari produk tersebut.
Tahapan yang terakhir atau yang keempat adalah pengecekan kembali atau biasa disebut follow up, ditahap ini para distributor diharapkan untuk menghubungi kembali konsumen dan menanyakan apakah ada perubahan atau tidak. Jika hasilnya positif maka dapat disarankan untuk mengkonsumsi produk tersebut kembali. Jika hasilnya kurang memuaskan dapat dilakukan pengecekan kembali dan memberikan saran produk, tetapi diikuti dengan pantangan selama mengkonsumsi produk ini. Biasanya yang diikuti pantangan adalah penyakit kronis (diabetes, kanker, ginjal, jantung). Dan tahapan ini akan menjadi roda yang akan terus bergulir, sehingga strategi ini dirasa efektif dalam menghadapi konsumen.

\section{KESIMPULAN DAN SARAN \\ Kesimpulan}

Dapat disimpulkan hasil penelitian yang dilakukan melalui wawancara, bahwa distributor tidak mencapai target disebabkan karena kurangnya edukasi tentang prospek negative, sehingga para distributor menjadi kurang percaya diri untuk melakukan presentasi berikutnya. Dan hal ini yang menjadi faktor utama penyebab tidak tercapainya target. Di perusahaan sendiri telah diberikan 7 Langkah dalam menjalankan bisnis ini yaitu : Impian dan Sikap, Pakai Produk, Buat Daftar Nama, Buat Janji Bertemu, Presentasi, Tindak Lanjut dan Gunakan Alat Bantu (cd, buku positif, dll). Tetapi langkah ini masih kurang tepat untuk diterapkan pada masing masing klasifikasi distributor, karena setiap klasifikasi memiliki karakteristik yang berbeda dan harus ditangani dengan strategi yang tepat.

\section{Saran}

Peneliti mengemukakan saran sebagai bahan pertimbangan Leaders Tiens International Group sebagai berikut :

1. Para leader harus lebih memberikan edukasi kepada para distributor baru tentang prospek negative, sehingga para distributor tidak hanya terpaku pada penolakannya saja.

2. Strategi yang cocok diterapkan ada 3 yaitu strategi sebagai pola, strategi sebagai perspektif dan strategi sebagai posisi.

Dimana strategi sebagai pola diterapkan saat para distributor menghadapi calon distributor, sedangkan strategi sebagai perpektif diterapkan untuk para distributor yang ingin mengembangkan karirnya, dan yang terakhir strategi sebagai posisi diterapkan saat menghadapi konsumen. 


\section{REFERENSI}

Ambar Sulistiyani, 2002, Perilaku Organisasi, Edisi Kedelapan, Jilid 2, Jakarta: Erlangga. (8)

Arikunto Suharsimi. 2010. Prosedur Penelitian Suatu Pendekatan Praktik. Jakarta: Rineka Cipta. (2)

Arikunto, S. 2006. Prosedur Penelitian Suatu Pendekatan Praktik. Jakarta : PT RINEKA CIPTA (3)

Denzin, Norman and Lincoln Yvanna S. 1994. Handbook of Qualitative Research, Sage Publications, New York. (7)

Emzir. 2010. Metodologi Penelitian Kualitatif : Analisis Data. Jakarta : Raja Grafindo. (4)

Henry Mintzberg et al. (1998). Strategy Safari, A Guided Tour Through The Wilds of Strategic Management (New York, London, The Free Press) (9)

Sugiono. 2009. Metode Penelitian Kuantitatif dan Kualitatif dan $R \& D$. Bandung : Alfabeta. (1)

Sutrisno Hadi, 2015, Prosedur Penelitian Suatu Pendekatan Praktik. Jakarta. Rineka Karya (5)

Yin, Robert, K. 2003. Studi Kasus Design dan Metode.Jakarta : Rajawali Pers. (6) 